\title{
Ketidakadilan gender dalam budaya Jawa dan Papua yang tercermin lewat novel Gadis Pantai dan novel Tanah \\ Tabu: Kajian sastra bandingan
}

\author{
Maria Sthefanny Putri Dewanty \\ Universitas Sebelas Maret Surakarta \\ Correspondence : reafalyn@gmail.com
}

\begin{abstract}
This article talks about the social class of women or what is commonly known as feminism that occurs in Java and Papua. The problem addressed in this article is to compare how gender injustice is experienced by women in Java and also in Papua. Where the geographical location of each region has a major influence on the value of feminism. The social environment in which they live greatly influences the life that is lived by women. This research was conducted using descriptive-qualitative methods. How does the author explain in detail that these women are described by each novel. How were women at that time very obedient to this gender inequality. It seems that their natures are very low compared to men. This difference is very obvious because indeed women are only used as a tool to satisfy lust. The data collection technique used was reading and listening through novels. With this data collection technique, conclusions will be drawn from the two contents of the novel. In these two novels, they are told in great detail about their struggle to get their rights as a woman. Women who are always looked down upon and weak. Their struggle to become other, which aims to strengthen themselves so that they are more familiar with and confident in themselves as a "woman". The author tries to describe the differences between the struggles of a woman in the two novels.
\end{abstract}

Keywords: feminism, social class, female character

\begin{abstract}
Abstrak
Artikel ini berbicara tentang kelas sosial perempuan atau yang biasa disebut dengan feminisme yang terjadi di tanah Jawa dan juga tanah Papua. Masalah yang dituju dalam artikel ini adalah membandingkan bagaimana ketidakadilan gender yang dialami oleh para perempuan di tanah Jawa dan juga di tanah Papua. Dimana letak geografis setiap daerah berpengaruh besar terhadap nilai feminisme. Faktor lingkungan sosial
\end{abstract}


tempat mereka tinggal sangat mempengaruhi kehidupan yang dijalani oleh perempuan. Penelitian ini dilakukan dengan menggunakan metode deskriptif-kualitatif. Bagaimana penulis menjelaskan secara rinci bahwa para perempuan ini digambarkan oleh masing-masing novel. Bagaimana perempuan pada zaman tersebut sangat patuh akan ketidaksetaraan gender tersebut. Terlihat sebagaimana kodrat mereka sangat rendah dibandingkan oleh laki-laki. Perbedaan ini sangat kentara karena memang perempuan hanya dijadikan alat untuk memuaskan hawa nafsu saja. Teknik pengumpulan data yang dilakukan adalah dengan membaca dan menyimak melalui novel. Dengan teknik pengumpulan data tersebut maka akan didapatkan kesimpulan dari kedua isi novel. Dalam kedua novel ini diceritakan begitu rinci mengenai perjuangan mereka untuk mendapatkan haknya sebagai seorang perempuan. Perempuan yang selalu dianggap rendah dan lemah. Perjuangan mereka untuk menjadi liyan, yang bertujuan untuk mengukuhkan diri supaya lebih memperkenalkan dan percaya diri terhadap diri seorang "perempuan". Penulis berusaha menggambarkan perbedaan dari perjuangan seorang perempuan dalam kedua novel tersebut.

Kata kunci: feminisme, kelas sosial, tokoh perempuan, ketidakadilan gender

\section{Pendahuluan}

Menurut Mursal Esten pengertian sastra atau kesusastraan adalah pengungkapan dari fakta artistik dan imajinatif sebagai manifestasi kehidupan manusia (Esten, 1978: 9) dan masyarakat melalui bahasa sebagai medium dan memiliki efek yang positif terhadap kehidupan manusia (kemanusiaan). Jadi sebuah karya sastra adalah gambaran dari manifestasi kehidupan sosial masyarakat. Pengarang mendapatkan ide untuk membuat sebuah karya sastra karena melihat lingkungan sosial di sekitarnya. Berbagai permasalah sosial di masyarakat dapat menjadi sebuah bahan untuk membuat karya sastra. Jika pengarang berhasil menggambarkan keadaan suatu masyarakat dengan baik, maka pembaca juga akan dengan mudah membayangkan keadaan yang dimaksud oleh sang pengarang. Sehingga pesan moral tentang kehidupan sosial masyarakat yang ingin disampaikan oleh pengarang dapat dipahami dengan mudah oleh pembaca.

Kajian yang diangkat dalam artikel ini adalah sastra bandingan. Dimana yang sudah diketahui bahwa sastra bandingan adalah membandingkan karya sastra satu dengan karya sastra yang lainnya. Diketahui bahwa sebuah karya sastra beranngkat dari keadaan sosial masyarakat mulai dari tradisi, pandangan estetika, serta tujuan berseni. Biasanya sastra bandingan saling berkaitan satu sama lain, berkaitan dengan karya sastra yang sudah pernah ada sebelumnya. 
Pada prinsipnya kajian sastra bandingan adalah studi pengamatan mendalam untuk melihat persamaan dan perbedaan, di samping mengamati keduanya, yang sekaligus mencari hubungan atau pertalian antara dua atau lebih karya sastra. Studi sastra bandingan pada umumnya membahas mengenai relasi di antara dua buah karya sastra atau lebih yang memiliki latar budaya yang berbeda di satu sisi, tetapi memiliki berbagai kesejajaran baik dari segi bentuk maupun konten di sisi lain.

Sebuah karya sastra dapat berangkat dari berbagai masalah sosial yang ada di lingkungan masyarakat. Tidak hanya kemiskinan, tetapi salah satu masalah sosial yang masih diperbincangkan hingga saat ini adalah tentang ketidakadilan gender. Ketidakadilan gender ini dialami oleh sebagian besar perempuan di Indonesia. Pada beberapa daerah di Indonesia masih mengutamakan atau meninggikan derajat laki-laki daripada perempuan. Maka muncullah istilah feminisme, dimana para perempuan memperjuangkan hak-hak yang sudah dirampas dan dieksploitasi.

Feminisme adalah hal yang sangat serius dalam sebuah lingkuangan sosial. Pengertian feminisme adalah gerakan dan kesadaran yang berangkat dari asumsi bahwa kaum perempuan pada dasarnya ditindas dan dieksploitasi, serta usaha untuk mengakhiri penindasan \& eksploitasi tersebut (Mansoer Fakih, 1995: 230). Penindasan yang diterima oleh sebagian kaum perempuan adalah perbedaan kelas sosial serta penindasan secara fisik. Feminisme adalah salah satu contoh permasalahan sosial yang masih kerap terjadi di beberapa daerah baik di dalam negeri maupun luar negeri. Indonesia masih memiliki daerah yang mengalami permasalah sosial feminisme yakni Jawa dan Papua. Feminisme sendiri muncul untuk memperjuangkan hak-hak perempuan yang merasa ditindas dan dieksploitasi. Pengeksploitasian yang terjadi sungguh mengharukan karena perempuan kehilangan hak-haknya dalam lingkungan sosialnya.

Kata feminisme muncul karena banyaknya perempuan yang memperjuangkan haknya untuk dapat setara dengan laki-laki. Beberapa faktor yang membuat teori feminisme ini muncul adalah stigma masyarakat. Mayarakat berpikir bahwa perempuan adalah makhluk yang lemah dan emosional maka tidak sepatutnya mendapat kedudukan yang strategis. Masyarakat beranggapan bahwa perempuan tidak layak untuk berada atau maju di ranah publik karena dianggap rendah. Tidak hanya stigma masyarakat tetapi juga dalam hal pendidikan. Perempuan sering dianggap tidak layak mendapatkan pendidikan yang tinggi karena status sosialnya sebagai perempuan adalah hanya mengerjakan seluruh pekerjaan rumah. Masyarakat memandang hal tersebut sebagai sebuah kodrat perempuan, maka dari itu pada zaman itu melarang para perempuan untuk menempuh pendidikan yang tinggi.

Selain stigma dan pendidikan, ada lagi faktor lain yang mempengaruhi pola pikir masyarakat terhadap perempuan yakni dalam segi ekonomi. Karena dalam masalah sosial perempuan tidak boleh mendapatkan gelar atau pendidikan yang 
tinggi dan dipandang hanya boleh melakukan pekerjaan domestik saja, maka dalam hal ekonomi perempuan juga dianggap lemah. Cukup hanya mengandalkan laki-laki (suami) yang akan memberinya sejumlah uang untuk dikelola. Uang tersebut pun hanya boleh digunakan untuk hal-hal yang masih berhubungan dengan kebutuhan rumah tangga. Selanjutnya faktor terakhir yang mempengaruhi pola pikir masyarakat terhadap perempuan adalah bahwa perempuan tidak selayaknya mendapatkan posisi yang strategis. Posisi strategis ini contohnya dalam kedudukan di sebuah pemerintahan atau organisasi dunia, kebanyakan masih didominasi oleh laki-laki hingga sekatang.

Pemikiran-pemikiran semacam itulah yang membuat citra perempuan dianggap lebih rendah dari laki-laki. Diskriminasi perempuan di dalam sebuah lingkungan sosial sangatlah kentara. Maka dari itu muncullah istilah feminisme, dimana para perempuan berjuang untuk mendapatkan hak-haknya. Dimana para perempuan ingin dianggap setara oleh laki-laki. Dimana perempuan ingin menuntut keadilan gender oleh stigma masyarakat yang selama ini menganggapnya rendah. Indonesia adalah salah satu negara dimana awalnya di beberapa daerah erat memegang stigma bahwa perempan hanya boleh melakukan pekerjaan domestik saja. Tetapi di Indonesia juga ada gerakan bernama "Indonesia Tanpa Feminisme" hal ini mendorong para perempuan di Indonesia untuk dapat mendapatakan pendidikan yang tinggi serta berusaha menunjukkan dirinya bahwa perempuan layak disamakan derajatnya dengan laki-laki.

Tetapi jika kita lihat dalam tulisan di dalam novel Gadis Pantai karya Pramoedya Ananta Toer dan juga Tanah Tabu karya Anindita S. Thayf menyatakan bahwa di beberapa daerah di Indonesia masih menerapkan ketidakadilan gender. Contoh daerah yang disebutkan di dalam novel tersebut adalah Jawa dan Papua. Dalam novel Gadis Pantai sangat jelas menceritakan kehidupan seorang perempuan Jawa yang hanya boleh melakukan pekerjaan domestik saja, dan bahkan hanya sebagai alat pelengkap di dalam sebuah rumah tangga. Berbeda dengan tokoh perempuan yang ada di dalam novel Tanah Tabu, bahwa perempuan yang ada di Papua mengalami kekerasan secara fisik. Bahkan perempuan di Papua dianggap sebagai sebuah barang saja yang dapat dengan mudah digunakan lalu dibuang jika sudah tidak berguna lagi.

Terlihat dalam kedua novel tersebut mengandung unsur feminisme yang kentara. Maka dari itu tujuan penulis mengambil unsur feminisme dari kedua npvel tersebut adalah karena salah satu bahasan yang paling dijunjung oleh kedua novel tersebut adalah tentang ketidakadilan gender. Dimana para perempuan menuntut haknya sebagai seorang makhluk hidup yang sama derajatnya dengan laki-laki. Bagaimana kedua novel ini memiliki perbedaan carita tentang ketidakadilan gender karena digambarkan di daerah yang berbeda dengan satu negara yang sama. Karena perbedaan daerah inilah yang membuat perlakuan ketidakadilan gender juga berbeda. Maka penulis ingin menganalisa 
perbedaan ketidakadilan gender dari kedua novel dengan menggunakan teknik pengumpulan data yakni membaca dan menyimak. Lalu kemudian dianalisa dan ditarik kesimpulan dari analisa tersebut.

Tujuan yang ingin dicapai dalam penelitian ini adalah untuk dapat mengetahui perbandingan yang terdapat dalam novel Tanah Tabu karya Anindita S. Thayf dan Gadis Pantai karya Pramoedya Ananta Toer. Hal yang dibahas dalam kedua novel tersebut sama, yakni tentang feminisme. Hanya yang membedakannya adalah daerah yang menjadi masalah feminisme tersebut. Karena Indonesia begitu luas, sehingga ada beberapa daerah yang memiliki masalah masyarakat yang sama hanya saja perlakuan yang didapatkannya berbeda. Artikel ini meninjau feminisme yang terjadi terhadap perempuan Jawa dan perempuan yang ada di tanah Papua. Feminisme yang dialami oleh kedua tokoh perempuan dengan daerah asal yang berbeda tersebut menjadi pusat perhatian karena perlakuan feminisme yang didapatkan cukup berbeda. Tetapi tidak hanya ditinjau dari perbedaan saja, tetapi juga perjuangan sesorang perempuan untuk menuntut haknya sebagai seorang manusia yang sama derajatnya. Perjuangan seorang perempuan yang ingin diakui bahwa bukanlah seorang makhluk yang lemah dan rendah. Tetapi perempuan adalah makhluk yang bisa disamakan dengan laki-laki. Tidak ada yang tinggi juga tidak ada yang rendah.

Metode yang digunakan dalam artikel ini adalah deksriptif-kualitatif. Metode ini berguna untuk mengumpulkan data lalu menarik kesimpulan dari data yang sudah dikumpulkan tersebut. Teknik pengumpulan yang dilakukan oleh penulis adalah dengan cara membaca dan menyimak kedua novel yang menjadi pokok pembahasan utama. Dengan membaca dan menyimak maka akan ditemukan permasalahan yang akan diangkat menjadi sebuah artikel. Metode ini berguna untuk menggambarkan secara rinci bagaimana permasalahan masyarakat yang dialami oleh si tokoh. Bagaimana sebuah masalah memiliki jalan keluarnya.

Teori Feminisme yang digunakan untuk membahas masalah ini adalah Feminisme Marxis yang dikemukakan oleh Karl Marx. Bagi Feminisme Marxis, penindasan kaum perempuan adalah bagian dari penindasan kelas dalam hubungan produksi. Senada dengan pandangan Karl Marx (dalam Soekanto, 2009: 38) yang mengatakan bahwa selama masyarakat terbagi atas kelas-kelas, maka pada kelas yang berkuasalah akan terhimpun segala kekuasaan dan kekayaan. Selama masih ada kelas yang berkuasa, eksploitasi terhadap kelas yang lebih lemah akan tetap terjadi. Dalam hubungannya dengan keterpurukan kaum perempuan, maka perempuan akan selalu menjadi kelas kedua setelah laki-laki.

\section{Hasil dan pembahasan}

Feminisme adalah sebuah gerakan sosial untuk mencapai keadilan gender atau kesetaraan hak terhadap perempuan. Penuntutan hak-hak perempuan yang 
sudah dirampas dan dieksploitasi. Gerakan feminisme memiliki tujuan untuk menumbuhkan kesadaran akan perlakuan terhadap perempuan yang selama ini selalu ditindas dan dieksploitasi hak-haknya. Gerakan feminisme ini pertama kali muncul di Inggris pada tahun 1792 lewat buku yang berjudul A Vindication of The Rights of Woman karya filsuf Inggris yang bernama Mary Wollstonecarft. Tetapi istilah feminisme banyak digunakan pada tahun 1808. Indonesia adalah salah satu negara yang memiliki gerakan feminisme. Sebenarnya hampir sebagian masyarakat Indonesia di zaman sekarang, perempuan sudah bisa dihargai dan disamaratakan dengan laki-laki.

Seperti contohnya Feminisme yang terjadi di Indonesia. Kita ketahui bahwa Indonesia terdiri dari beribu-ribu pulau. Salah satu pulau yang terkenal akan feminisme adalah pulau Jawa. Kita ketahui bahwa ada tokoh perempuan Jawa yang menjunjung tinggi feminisme. Tokoh ini bernama R. A. Kartini. Kartini adalah seorang perempuan Jawa yang melihat bahwa pada zaman itu perempuan Jawa sudah ditindas haknya untuk menempuh sebuah pendidikan. Perempuan Jawa pada saat itu hanya dibolehkan untuk mengurus rumah, menikah, dan mempunyai anak. Terlihat bahwa pada masa itu kaum perempuan ditindas dengan segala bentuk aturan yang tidak memberikan kebebasan untuk memilih. Pada akhirnya Kartini mengajak para perempuan untuk tidak pantang menyerah dalam menyetarakan hak-haknya dengan kaum laki-laki.

Kajian feminisme yang akan dibahas dalam artikel ini adalah dari dua buah novel yang dianalisa melalui sastra bandingan. Ketiadilan gender yang dialami oleh kedua belah novel berbda. Perlakuan yang didapatkan oleh kedua tokoh perempuan yang ada di kedua novel juga berbeda. Maka dari itu diperlukan kajian sastra bandingan untuk dapat menarik kesimpulan tentang perbedaan dan persamaan dari kedua novel tersebut. sebuah karya sastra perlu adanya kajian sastra bandingan untuk dapat merelasikan dengan karya sastra yang pernah ada sebelumnya. Sastra bandingan sangat erat kaitannya dengan kritik sastra. Maka dari itu sastra bandingan sangat diperlukan untuk penelitian karya sastra. Sehingga sebuah karya sastra yang ditulis oleh pengarang dapat diketahui kelebihan dan kekurangannya.

Perempuan adalah figur yang patut diperebutkan oleh laki-laki, terutama karena kecantikan dan kebolehannya. Poin pentingnya adalah bahwa perempuan harus setia kepada laki-laki (Endraswara: 2011: 144 ). Hal ini yang menyebabakan seorang perempuan harus patuh dan levelnya selalu berada di bawah laki-laki. Perempuan bagi laki-laki hanya dijadikan alat pemuas serta hanya untuk melayaninya saja. Pekerjaan selebihnya tidak sepatutnya dilakukan oleh perempuan. Contohnya bagi masyarakat Jawa, perempuan dianggap hanya boleh mengenal tentang sumur, kasur, dan dapur. Jadi perempuan Jawa hanya boleh mengenal pekerjaan-pekerjaan domestik saja, seperti memasak, mencuci, dan melayani laki-laki (suami). 
Feminisme yang mencolok disini adanya perbedaan gender. Menurut Emzir \& Rohman, (2015: 156) gender merupakan sifat yang melekat pada kaum laki-laki dan perempuan yang dibentuk oleh faktor-faktor sosial, budaya, dan agama. Karena adanya perbedaan gender inilah yang membuat kaum perempuan lebih terlihat rendah dibandingan dengan kaum laki-laki. Bagi laki-laki perempuan adalah makhluk lemah yang hanya bisa bergantung pada laki-laki. Maka dari itu tercetuslah kata "emansipasi". Makna paling utama dalam emansipasi wanita adalah persamaan hak dan kesetaraan gender, (Citra, 215: 66). Oleh karena itu, wujud dari emansipasi merupakan bentuk perjuangan kaum perempuan untuk mewujudkan kesetaraan gender baik dalam bidang sosial, ekonomi, politik dan pendidikan. Penyebab terjadinya emansipasi adalah adanya ketidakadilan gender yang dialami perempuan.

Pada pembahasan berikut akan dijelaskan meengenai kedua novel yang mengangkat masalah sosial yakni feminisme. Novel tersebut adalah Gadis Pantai karya Pramoedya Ananta Toer dan Tanah Tabu karya Anindita S. Thayf. Sebelumnya seperti yang kita sudah ketahui bahwa Pramoedya Ananta Toer adalah sastrawan besar Indonesia yang karya-karyanya sempat dilarang oleh pemerintah untuk dikonsumsi. Karena karya-karyanya selalu berisikan tentang sindiran terhadap masalah-masalah sosial ataupun politik. Sehingga pemerintah merasa terancam dengan adanya karya-karya dari Pramoedya Ananta Toer. Dari sekian banyak karya yang sudah dihasilkannya, Pramoedya mengangkat salah satu masalah sosial yang cukup diresahkan di berbagai kalangan perempuan pada zaman tersebut, yakni novel Gadis Pantai.

Gadis Pantai terbit pertama kali pada tahun 1987, novel ini menceritakan tentang situasi feodalisme yang terjadi di tanah Jawa pada zaman tersebut. Novel ini mengangkat permasalah sosial yang sangat krusial pada saat itu, yakni feminisme. Karena di dalam novel Gadis Pantai, si tokoh perempuan yakni gadis pantai dipaksa untuk menikah dini karena urusan hutang keluarganya. Pada zaman tersebut pernikahan dini dengan alasan hutang sudah tidak bisa dihindari lagi. Dengan sangat terpaksa gadis pantai mau tidak mau harus menerima pernikahan tersebut. Pernikahan yang ia lakukan adalah dengan seorang Bendoro atau Priyayi. Dimana seorang Bendoro atau Priyayi seseorag yang sudah cukup berumur dan memiliki istri cukup banyak.

Dalam novel Gadis Pantai dijelaskan betapa si tokoh perempuan sangatlah sengsara. Singkatnya setelah ia melahirkan maka Bendoro atau Priyayi tersebut akan menceraikannya, tetapi anak yang sudah ia lahirkan harus dibawa dan diasuh oleh Bendoro atau Priyayi. Setelah itu gadis pantai mau tidak mau harus merelakan anak yang sudah ia kandung selama 9 bulan dan juga harus angkat kaki dari rumah itu. Aturan pada zaman tersebut adalah Bendoro atau Priyayi akan setia menikah dengan satu orang jika perempuan tersebut sederajat dengannya atau dari kalangan bangsawan. Jika belum menemukan perempuan yang sederajat dengannya maka, Bendoro atau Priyayi secara semena-mena akan 
menikahi berkali-kali perempuan yang derajatnya rendah di bawahnya untuk hanya dapat melahirkan anak saja yang kemudian akan dicerai. Begitu seterusnya hingga Bendoro atau Priyayi tersebut mendapatkan perempuan dari kalangan atas atau bangsawan.

Gadis Pantai juga mengalami perlakuan yang semena-mena dan hanya boleh melakukan pekerjaan-pekerjaan domestik saja. dapat dibayangkan pada zaman tersebut perempuan dari kalangan bawah sangatlah menderita dan dieksploitasi hak-hak kebebasannya. Seperti yang sudah disebutkan bahwa seorang perempuan yang berasal dari kalangan bawah tidak berhak menolak lamaran atau ajakan nikah dari seorang Bendoro atau Priyayi. Apalagi Bendoro atau Priyayi tersebut adalah seseorang yang sudah memberikan hutang kepada keluarga si perempuan. Disini hak kebebasan sebagai seorang perempuan untuk menolak sudah dieksploitasi. Sehingga tokoh perempuan tidak bisa menolak dan harus menerima ajakan nikah tersebut. Pernikahan dini terhadap perempuan pada zaman tersebut juga sangatlah banyak terjadi. Karena ekonomi keluarga yang begitu rendah sehingga pihak orangtua lebih merelakan melepas anaknya perempuan untuk segera dipinang oleh laki-laki.

Berbeda dengan novel Tanah Tabu karya Anindita S. Thayf. Novel ini terbit pada tahun 2009. Anindita melihat kehidupan di tanah Papua yang sangat jauh dari peradaban kemajuan teknologi. Sehingga membuatnya tertarik untuk mengambil latar cerita di tanah Papua. Anindita mengambil perempuan di Papua karena seringkali masyarakat acuh terhadap saudara-saudara yang ada di tanah Papua. Bahkan tanah Papua dianggap pinggiran dan ketinggalan zaman. Sehingga Anindita ingin mengambil perempuan di tanah Papua karena ingin menonjolkan gagasan dan menggambarkan keadaan pinggiran yang ada di Papua. Anindita menggambarakan tokoh Mabel, seorang perempuan yang hidup miskin di Papua. Dengan ekonomi yang sangat rendah Mabel berusaha untuk terus melanjutkan hidup walaupun begitu sulit dilewati.

Mabel hidup dengan seorang suami yang sangat kejam kepadanya. Mabel sering mendapatkan perlakuan kasar yang diberikan oleh suaminya. Pada akhirnya Mabel menyerah hidup bersamanya sehingga memilih untuk meninggalkannya dan hidup mandiri. Disamping itu Mabel juga memiliki tetangga yang sudah bersuami. Tetangganya tersebut juga mendapatkan kekerasan secara fisik oleh suaminya. Jadi dapat dibayangkan bahwa perempuan-perempuan di Papua sering mendapatkan kekerasan secara fisik. Terkadang tidak hanya fisik tetapi juga lewat kata-kata. Maka dari itu perlu adanya perlindungan terhadap perempuan di Papua. Mabel sebagai seseorang yang sudah mengalami pahitnya hidup sebagai perempuan di Papua, maka dia ingin berusaha mengubah hidupnya menjadi lebih baik lagi.

Perempuan di tanah Papua hanya sebagai pelampiasan nafsu semata, jadi bisa dikatakan bahwa perempuan di tanah Papua mengalami pelecehan secara seksual. Karena terkadang perempuan di Papua tidak hanya melayani suaminya 
saja, tetapi juga dipaksa untuk melayani para tentara pada zaman dahulu tanah Papua didiami oleh para penjajah. Dengan mengaca apa yang sudah dialami perempuan yang ada di Papua, maka tidak ada salahnya jika perempuan di Papua menginginkan haknya. Hak kebebasan yang dituntut karena selama ini merasa haknya ditindas dan dieksploitasi. Maka seorang seperti Mabel ingin kebebasan hak untuk dirinya. Disini Anindita menggambarkan bahwa seorang Mabel memiliki hewan peliharaan yang sangat ia sayangi dan setia. Anindita lucunya menggabungkan anjing dan babi yang memiliki nama masing Pum dan Kwee.

Tetapi dalam perjalannya ketika Mabel mendapatkan siksaan serta diikat Pum dan Kwee ingin menolongnya, tetapi naas mereka berdua kehilangan nyawanya karena tertimpa oleh batu yang sangat besar. Mabel sangat sedih karena menurutnya hanya mereka berdua adalah sahabat yang paling dekat dengannya. Sehingga sekarang Mabel harus hidup berjuang sendiri. Mabel beranggapan bahwa orang-orang asing yang datang ke Papua hanya ingin mengambil kekayaan yang ada di tanah Papua. Mabel telah memperlihatkan keeksistensinya sebagai seorang perempuan yang berjuang untuk generasi kedepannya khususnya di Papua serta telah menjadi sosok perempuan yang bisa diandalkan dan tentunya memiliki pemikiran yang modern dibandingkan dengan perempuan Papua lainnya. Bahkan Mabel melawan penduduknya sendiri karena sudah menjadi penjilat. Disinilah ketegaran Mabel sebagai seorang perempuan yang banyak dihiraukan oleh masyarakat.

Gambaran perempuan dari novel Gadis Pantai dan juga Tanah Tabu membuat jiwa feminisme semakin meningkat. Mengingatkan bahwa pada zaman itu perempuan masih dianggap sangat rendah. Sehingga muncullah gerakan untuk lebih meningkatkan citra perempuan di mata masyarakat. Membuktikan bahwa perempuan layak dipandang dan disamaratakan haknya dengan laki-laki. Kajian sastra bandingan menemukan bahwa kedua novel tersebut memiliki perbedaan yakni perlakuan yang didapatkan oleh Gadis pantai dan juga Mabel. Tetapi persamaan yang ditemukan adalah bahwa mereka berdua sama-sama menuntut hanya untuk lebih dihargai dan dihormati oleh masyarakat sosial.

Perempuan di tanah Papua lebih mengalami kekerasan secara fisik tetapi perempuan di tanah Jawa lebih kepada kekerasan batiniah. Karena yang kita ketahui juga bahwa hampir sebagian besar masyarakat di Papua adalah seorang pekerja kasar. Sehingga mereka terbiasa untuk melakukan hal-hal kasar tidak hanya kepada binatang tetapi juga kepada perempuan. Karena mereka tahu perempuan adalah makhluk yang lemah sehingga mereka selalu melampiaskan kemarahannya atau kekecewaannya dengan cara memukuli perempuan atau istrinya. Walaupun novel tersebut terbit di tahun yang berbeda tetapi perempuan yang digambarkan oleh Pramoedya dan juga Anindita sepertinya hidup di era yang sama. Karena pada novel Tanah Tabu disebutkan bahwa masih ada tentara belanda alias penjajah. Sebaliknya pada novel Gadis Pantai disebutkan bahwa pada zaman itu sedang berada di era Hindia-Belanda. 
Feminisme yang terjadi pada zaman tersebut patut untuk diperjuangkan. Hak perempuan yang ditindas dan didominasi oleh laki-laki harus disamaratakan. Maka dari itu Mabel dan Gadis pantai ingin membuktikkan bahwa seorang perempuan juga layak untuk dihormati. Penuntutan hak antara perempuan Jawa dan Peremouan Papua hampir sama yakni kebebasan. Dimana yang mereka inginkan hanyalah sebuah kebebasan yang membuat mereka tidak terikat aturan-aturan kuno. Tetapi ada beberapa hal yang disalahartikan dengan adanya teori feminisme. Terkadang feminisme dipandang menjadi sesuatu yang mendorong seorang perempuan untuk membenci laki-laki. Padahal feminisme tidak mengajarkan seorang perempuan untuk membenci laki-laki. Hal lain yang membuat feminisme disalahartikan adalah, feminisme dianggap ingin melebihi derajat laki-laki padahal feminisme lebih berfokus pada kesetaraan gender. Perempuan hanya ingin hak nya sebagai seorang makhluk hidup disamaratakan dengan laki-laki.

Ada beberapa masyarakat juga mengatakan bahwa feminisme melawan kodrat alamiah manusia. Kodrat alamiah manusia yang dianggap bahwa perempuan harus menurut dan menghormati laki-laki. Padahal maksud kajian dari feminisme hanya ingin melawan ketidakadilan gender yang terjadi di dalam suatu masyarakat. Karena beberapa laki-laki juga menyalahartikan kehormatan yang dimilikinya, dengan semena-mena menjadi seorang laki-laki dengan segala aturan serta kekerasan baik fisik maupun verbal. Masyarakat yang menganggap bahwa seorang perempuan sudah teracuni oleh teori feminisme lalu tdak ingin memiliki anak adalah salah. Feminisme tidak mengajarkan perempuan untuk tidak memiliki anak dan melarang untuk seorang perempuan berhubungan intim dengan laki-laki. Tetapi memiliki anak adalah sebuah pilihan, dan memang kodrati seorang wanita adalah mengandung dan melahirkan anak.

Mitos lain adalah bahwa seseorang yang percaya akan teori feminisme adalah seorang perempuan yang tidak percaya akan ikatan pernikahan. Padahal tidak, ikatan suatu pernikahan adalah janji setia hingga mati. Hanya saja janji tersebut berisi untuk saling menjaga bukan menyakiti. Hal yang disalahkan adalah ketika saat rumah tangga terjadi kekerasan secara fisik ataupun verbal. Itu adalah hal yang tidak sepatutnya terjadi, dan kekerasan tersebut banyak dialami oleh paera perempuan. Sehingga hal tersebut yang ingin diperjuangkan supaya laki-laki tidan dengan gampangnya menyiksa perempuan. Perkembangan feminisme untuk sekarang ini perlu diacungi jempol. Karena dengan adanya teori feminisme masyarakat semakin paham bahwa semua orang perlu berkembang dan semua orang perlu adanya pengakuan serta dihargai.

Maka dari itu seorang perempuan ingin memiliki kebebasan yang sama dimiliki oleh laki-laki. Perempuan hanya ingin dihargai dan dihormati keadaanya. Perempuan hanya ingin menjelaskan bahwa laki-laki dan perempuan adalah dua makhluk dengan kodrat yang sama. Walau gerakan feminisme telah ada cukup lama, namun ketidakadilan berbasis gender hingga saat ini masih 
tetap saja terjadi. Beberapa perempuan saat ini sudah bisa mengakses dunia pendidikan dan meniti karir. Berikut beberapa sektor yang masih belum sepenuhnya adil bagi perempuan:

\section{Stigma}

Norma sosial yang terbangun di masyarakat selain mencipta pembagian peran sosial yang tidak adil bagi perempuan, juga memberikan stigma bahwa perempuan makhluk yang lemah, dan emosional, maka dari itu masyarakat kemudian beranggapan bahwa perempuan tidak layak berada di ranah publik apalagi menduduki posisi strategis, baik dalam struktur pemerintahan maupun swasta.

2. Pendidikan

Dalam keluarga dan masyarakat yang masih memegang teguh norma gender yang tidak adil bagi perempuan, beranggapan bahwa pendidikan untuk perempuan tidaklah penting, karena menurut mereka perempuan bila sudah menikah akan di rumah saja mengurus keluarga. Lebih dari itu, Survei National Science Foundation pada rentang 2010-2014, sebagaimana dimuat di Tirto.id, terdapat 72.446 perempuan dan 104.425 laki-laki peraih gelar doktor. Dengan demikian maka peran perempuan yang dapat mengajar di Perguruan Tinggi masih terbatas. Hal itu terjadi menurut Kemendikbud karena adanya persepsi bahwa perempuan hanya bertanggung jawab dalam urusan domestik membuat mereka kurang termotivasi untuk mengambil gelar S2 atau S3 sebagai syarat pengajar perguruan tinggi.

3. Ekonomi

Dalam norma sosial yang tidak adil gender, peran perempuan yang sudah menikah di dalam keluarga sebagai ibu rumah tangga, dan tidak wajib mencari nafkah. Pada akhirnya norma sosial tersebut membuat perempuan secara ekonomi bergantung pada laki-laki (suami). Imbas dari pembakuan peran gender tersebut berlaku di dunia kerja, dimana upah perempuan lebih rendah dibanding upah laki-laki. Pada tahun 2015, rata-rata upah pekerja perempuan sebesar 1,68 juta rupiah, sedangkan pekerja laki-laki sebesar 1,94 juta rupiah. Walau kesenjangan upah antar gender terus menurun, rata-rata pekerja perempuan masih mendapatkan upah 13,83 persen lebih rendah dibandingkan laki-laki. Hal itu terjadi selain perempuan dipandang sebagai manusia nomor dua setelah lakilaki, juga karena menganggap perempuan bukan pencari nafkah utama, ia hanya membantu saja.

\section{Posisi strategis}

Menurut Badan Kepegawaian Negeri (BKN), persentase PNS perempuan di Indonesia masih belum sebanding, yakni 39,70\% perempuan dan 60,3\% lakilaki. Selain itu jumlah perempuan yang menduduki posisi eselon I dan II masih minim dibanding laki-laki. Begitu juga posisi strategis lainnya baik di pemerintahan, badan dunia, maupun swasta, masih didominasi oleh laki-laki. 
Hal demikian terjadi karena masih mengakarnya nilai-nilai sosial yang tidak adil gender bagi perempuan.

Dari beberapa sektor yang disebutkan sudah cukup jelas, sebenarnya hasil dari analisa yang sudah dilakukan, masih ada beberapa feminisme yang terjadi di Indonesia. Tetapi jangan beranggapan bahwa teori feminisme adalah teori yang menyesatkan. Feminisme hanya ingin keadilan gender atau kesetaraan gender. Perempuan hanya ingin dianggap sama dengan laki-laki. Masalah kodrati alami perempuan atau istri harus tunduk dengan laki-laki atau suami adalah hal yang lumrah. Asalkan seorang laki-laki ataupun suami juga harus bisa menghargai istrinya serta menyayanginya. Stigma masyarakat yang negatif adalah stigma masyarakat yang harus dihilangkan. Kini dunia mulai berkembang dengan pesat yang dipenuhi juga dengan berbagai macam teknologi canggih. Maka dari itu diperlukan seseorang yang memiliki wawasan yang luas serta pemikiran yang terbuka.

Seseorang yang memiliki wawasan luas sekarang ini sangat dihargai. Seseorang yang memiliki pemikiran terbuka adalah seseorang yang bijaksana. Sekarang ini perempuan berusaha untuk terus disamaratakan haknya dengan laki-laki. Contohnya Indonesia sekarang seoang menteri ada juga yang perempuan, dan hasil kerjanya pun juga cukup memuaskan. Bahkan Indonesia memiliki presiden ke-5 yakni seorang wanita. Maka tak dihiraukan lagi bahwa perempuan juga bisa memimpin. Kepemimpinan tidak hanya milik laki-laki saja. lewat dua novel Gadis Pantai dan juga Tanah Tabu penulis ingin berbagai bahwa saling menghormati adalah hal yang indah. Apapun yang berhubungan dengan penyelewengan hak harus diberantas. Maka dari itu hidup saling berdampingan adalah hal yang indah.

Pendidikan yang layak juga patut diemban oleh laki-laki atau perempuan. Bahkan pada zaman sekarang banyak perempuan yang melanjutkan studinya hingga S3. Padahal di zaman dahulu pendidikan S3 hanya bisa dilakukan oleh laki-laki. Feminisme menjadi salah satu alternatif model dalam melakukan penelitian kualitatif. Banyak persoalan yang sejatinya ketika didekati dengan kacamata laki-laki maka terjadi penyeselesaian yang tidak tepat bahkan dalam persoalan-persoalan tertentu menjadi bias gender. Sehingga rentan terhadap ketidakadilan dan kesewenang-wenangan. Fokus penelitian ini sebenarnya terletak di dalam perbedaan mendasar antara laki-laki (male) dan perempuan (famale) serta akibat perbedaan tersebut dalam kehidupan sosial politik. Fokusnya berupaya membawa perbedaan tersebut ke dalam keterbukaan untuk menunjukkan posisi subordinat kaum perempuan dan untuk menjelaskan sistem ekonomi dan politik dunia yang dipandang diskriminatif terhadap posisi perempuan. Untuk itu Feminisme menjadi salah satu pendekatan yang digunakan dalam penelitian kualitatif diharapkan mampu mengembalikan akar persoalan sosial, budaya, politik, ekonomi dan keagaamaan untuk dijawab 
menjadi solusi yang lebih feminis di antara persoalan-persoalan yang beraroma hegemoni kaum patriarki.

Feminisme yang ditanggung dalam Novel Tanah Tabu perjuangan yang dilakukan oleh Mabel, Mace, dan Mama Helda. Mereka bertiga sadar bahwa sudah ditindas oleh kaum laki-laki. Mereka berjuang untuk dapat terbebas dari penindasan tersebut. Mereka bebas menentukan pilihan yang mereka anggap benar dan berani bertanggung jawab atas pilihan tersebut. Transendensi dilakukan oleh Mabel, Mace, dan Mama Helda. Mereka menjadi perempuan pekerja, perempuan intelektual, perempuan transformasi sosialis, dan perempuan mengikuti kelompok dominan. Perjuangan tiga tokoh perempuan, yakni Mabel yang bertahan hidup sebagai janda, sekaligus hadir untuk menolak keberadaan tambang emas. Mace berjuang membesarkan dan menyekolahkan anak perempuannya. Mama Helda berjuang menyelamatkan dirinya dan anakanaknya dari suaminya yang suka memukul. Dengan perjuangan tersebut, ketiga tokoh perempuan di dalam novel ini menghilangkan stereotip bahwa perempuan lemah dan tidak mampu melawan ketertindasan pada dirinya. Bahkan di dalam cerita, salah satu tokoh perempuan, yaitu Mabel sangat dihormati oleh masyarakat Papua karena keberaniannya.

Berbeda halnya dengan Novel Gadis Pantai, karena persoalan perempuan di sini adalah perempuan yang tubuhnya dijadikan objek seks dan sarana reproduksi oleh lakilaki. Perbedaan latar sosial dalam novel yakni stratifikasi sosial kehidupan bangsawan dan "wong cilik" di pesisir utara Rembang pada masa kolonial ikut mendorong lahirnya ketidakadilan gender. Prinsip bibit, bobot, bebet (kualitas fisik, status, kehartaan) menjadi kriteria pokok. Yang dijaga adalah jangan sampai terjadi perkawinan dengan orang biasa (wong cilik). Kesadaran ini besar sekali karena priyayi ingin mempertahankan status, syukurlah apabila dapat meningkatkan (Kartodihardjo, 1987:186-187).

\section{Kesimpulan}

Faktor yang dapat mempengaruhi terjadi ketidakadilan gender karena stigma masyarakat yang terus-menerus dibangun bahwa perempuan adalah makhluk yang lemah dan derajatnya selalu dibawah laki-laki. Dari kedua novel yang berjudul Gadis Pantai dan juga Tanah Tabu membuktikkan bahwa perempuan pada zaman dahulu masih dianggap sangat rendah. Tetapi hanya di beberapa daerah saja yang masih menganggap bahwa perempuan harus selalu dibawah laki-laki. Mulai dari segi pendidikan yang terkadang perempuan tidak diperbolehkan mengemban pendidikan yang tinggi. Pendidikan yang tinggi hanya diperbolehkan untuk laki-laki saja. Masalah posisi yang strategis perempuan pun dilarang untuk menempatinya. Sehingga dalam pemerintahan atau organisasi dunia, anggota serta kepemimpinan masih didominasi oleh lakilaki. 
Sastra bandingan disini berguna untuk dapat melihat perbedaan yang terdapat dari kedua novel tersebut. Sehingga dengan pengumpulan data menyimak dan membaca maka dapat ditarik kesimpulan bahwa feminisme masih sering terjadi hingga sekarang, tetapi terkadang keadaan geografis dapat membuat perbedaan. Perbedaan inilah yang membuat penulis dapat menemukan kajian sastra bandingan dari kedua novel tersebut. Karena kedua novel tersebut menga,bil dari latar belakang wilayah yang berbeda yakni antara Jawa dan Papua. Karena perbedaan wilayah ini perlakuan yang di dapatkan oleh tokoh perempuan dari kedua novel tersebut juga berbeda. Feminisme adalah salah satu gerakan yang dapat memacu seorang perempuan untuk terus maju dan pantang menyerah agar memperjuangkan haknya yang selama ini ditindas dan dieksploitasi oleh laki-laki.

Para perempuan dari kedua novel tersebut berusaha memperlihatkan kepada masyarakat bahwa perempuan bukanlah makhluk yang lemah. Tetapi perempuan juga bisa disamaratakan oleh laki-laki. Perempuan hanya ingin haknya tidak ditindas secara terus-menerus. Perempuan juga ingin mengemban pendidikan yang tinggi supaya lebih dianggap berada dan dihormati. Pada era sekarang Indonesia sudah mulai menghargai keberadaan perempuan. Sekarang banyak sekali perempuan yang mengambil jalan untuk berpolitik. Bahkan presiden Indonesia yang ke- 5 adalah seorang perempuan. Tetapi Indonesia juga tak luput adalah negara kepulauan yang sangat besar, jadi tidak menutup kemungkinan bahwa di beberapa daerah yang ada di Indonesia masih menganggap bahwa perempuan lebih rendah derajatnya dibandingkan dengan laki-laki.

\section{Daftar pustaka}

Anisa Kurniawati, L. L. (2018). Kajian Feminisme dalam Novel "Cantik itu Luka" Karya Eka Kurniawan. Parole: Jurnal Pendidikan Bahasa dan Sastra Indonesia, 195-206.

Emzir, R. (2015). Teori dan Pengajaran Sastra. Jakarta: Rajawali Pers. Endraswara, S. (2013). Metodologi Penelitian Sastra. Jakarta: Buku Seru.

Hidayati, N. (2018). Teori Feminisme: Sejarah, Perkembangan, dan Relevansinya dengan Kajian Keislaman Kontemporer. Jurnal Harkat, 2129.

Karim, A. (2014). Feminisme: Sebuah Model Penelitian Kualitatif. Jurnal Sawwa, 83-98.

Kartodihardjo, S. (1987). Perkembangan Peradaban Priyayi. Yogyakarta: Gajahmada University Press.

Maulana, A. M. (2013). Feminisme Sebagai Diskursus Pandangan Hidup. Jurnal Kalimah, 271-286. 
M, Citra (2015). Pemahaman Emansipasi Wanita (Studi Hermeneutika Makna Emansipasi Wanita dalam Pemikiran R. A. Kartini pada Buku Habis Gelap Ternitlah Terang). Jurnal Komunikasi, 65-70.

Nur Dwiana Muslimah, S. P. (2019). Perjuangan Tokoh Perempuan Jawa dalam Novel The Chronicel of Kartini Karya Wiwid Prasetyo (Kajian Feminisme dan Pendidikan Karakter). BASASTRA Jurnal Bahasa, Sastra dan Pengajarannya, 125-136.

Umar, T. (2006). Propaganda Feminisme dan Perubahan Sosial. Jurnal Komunikasi, 205-214. 